DOI: https://doi.org/10.18371/fp.3(43).2021.263842

УДК 336.717 .18

\title{
ХАРАКТЕРИСТИКА ПІДСИСТЕМ СИСТЕМИ УПРАВЛІННЯ ЛІКВІДНІСТЮ У ЗАБЕЗПЕЧЕННІ ФІНАНСОВОЇ БЕЗПЕКИ ВІТЧИЗНЯНИХ КОМЕРЦІЙНИХ БАНКІВ
}

\author{
ПУТІНЦЕВА Тетяна Володимирівна \\ аспірант Університету банківської справи \\ ORCID ID: https://orcid.org/0000-0002-7640-7080
}

\begin{abstract}
Анотація. B статті визначені значущість і взаємозв'язок стану управління ліквідністю комериійного банку (КБ) у забезпеченні його фінансової безпеки (ФБ). Критично проаналізовані підсистеми наукового супроводу, а також нормативно-правого, організаційного, методичного, управлінського, інформачійно-аналітичного, кадрового ци технологічного забезпечення системи управління ліквідністю КБ. Виявлено позитивний/негативний вплив зазначених підсистем на фінансову безпеку комериійного банку (ФБКБ) загалом і такі ї̈ складові, як: боргова, валютна, депозитна, інвестиційна, кредитна, податкова, ресурсоутворювальна безпеки, безпеку у сфері міжнародних розрахунків і платежів, а також безпеки доходів $i$ витрат та ліквідності КБ.
\end{abstract}

Ключові слова: комериіийний банк, ліквідність, управління ліквідністю, підсистеми системи управління ліквідністю, фінансова безпека комериійного банку, складові фінансової безпеки комериійного банку.

Постановка проблеми. Фінансова безпека комерційного банку (ФБКБ) значною мірою зумовлюється станом його ліквідності в усіх іiї проявах, а відтак, великого значення набуває розбудова досконалої системи управлін-
Аннотация. $B$ cmambe определень значимость и взаимосвязь состояния управления ликвидностью коммерческого банка (КБ) в обеспечении его финансовой безопасности (ФБ). Критически проанализированы подсистемы научного сопровождения, а также нормативно-правого, организачионного, методического, управленческого, информационно-аналитического, кадрового и технологического обеспечения системь управления ликвидностью КБ. Выявлено позитивное/негативное влияние указанных подсистем на финансовою безопасность коммерческого банка (ФБКБ) в целом и такие ее составляющие, как: валютная, депозитная, долговая, инвестииионная, кредитная, налоговая, ресурсообразовательная безопасности, безопасность в сфрере международных расчетов и платежей, а также безопасности доходов и расходов и ликвидности КБ.

Ключевые слова: коммерческий банк, ликвидность, управление ликвидностью, подсистемы системы управления ликвидностью, финансовая безопасность коммерческого банка, составляющие финансовой безопасности коммерческого банка.

ня цим одним з найважніших маркерів функціонування банківських установ.

Досконалість же системи управління ліквідності комерційного банку (КБ) зумовлюється станом їі підсистем (наукового супроводу, нормативно- 
правового, організаційного, методичного, управлінського, облікового, інформаційно-аналітичного, кадрового, технологічного забезпечення), які залежно від статус-кво у цій сфері дозволяють підвищити/знизити рівень ФБКБ.

Для формування дієвої системи управління ліквідністю у забезпеченні ФБКБ слід застосовувати комплексний підхід до формування зазначених підсистем, оскільки лише в такому разі можливе вжиття дієвих заходів для підвищення ФБКБ.

Аналіз досліджень та публікацій. Питаннями формування системи управління ліквідністю КБ, виявленням проблем, недоліків, невирішених питань у цій сфері займалися такі вітчизняні й зарубіжні дослідники, як: Д. Гурський, Л. Залуніна, П. Заторскі, Ю. Максимова, В. Міщенко, М. Мрлікова, Г. Панасенко, А. Сомик, В. Ткачук, Г. Юркова.

Проте, у сучасній економічній літературі немає однозначного тлумачення впливу системи управління ліквідністю КБ загалом і іï окремих підсистем на ФБКБ, а відтак ця проблематика вимагає подальших поглиблених досліджень.

Метою статті є визначення стану формування системи управління ліквідністю КБ й іï окремих підсистем на забезпечення ФБКБ.

Виклад основного матеріалу дослідження. Підсистемам управління ліквідністю у забезпеченні ФБКБ, попри наявні позитивні риси, притаманні й численні недоліки. Зокрема, зберігається неоднозначність тлумачення сутності ліквідності КБ та іï різновидів, рівнів, чинників, що піi зумовлюють; індикаторів оцінки; методів управління нею і побудови його цілісної системи; іii місця і ролі у забезпеченні ФБКБ; недостатньо вивчена природа ризиків, що супроводжують формування, розподіл та використання ліквідності КБ, вбачається недостатня увага до їх моделювання.

Чинна нормативно-правова база не регламентує належним чином всі аспекти управління ризиком утрати ліквідності; в ній відсутні: усталеність й однозначність тлумачення норм; виокремлення ліквідності КБ для вітчизняного і міжнародного ринків, формування ліквідних міжнародних активів українських банківських установ, що покривають їх зовнішні боргові 30бов'язання.

НБУ, встановлюючи нормативи ліквідності, багато років лише опосередковано брав до уваги рівень капіталізації КБ, їх масштаб/розмір, специфіку діяльності, доцільність диференційованого (стандартного й спрощеного) порядку звітності для перевірки необхідних безпекових показників, що не могло не позначатися негативно на рівні їх ФБ. Формули, що визначали значення таких нормативів, не враховували й інші чинники, що вливають на ліквідність КБ. Водночас, середні значення нормативів не враховують розмежування КБ на такі, що мають дефіцит чи надлишок ліквідності.

Норматив Н5 (поточної ліквідності) не враховував, що: не всі депозити залишать КБ, не всі кредити будуть погашені; враховуються статичні залишки 3 урахуванням строковості. Натомість, LCR (коефіцієнт покриття ліквідністю) моделює ліквідну позицію КБ за умов реалістичного стресу, оперує очікуваними майбутніми грошовими потоками, де різні складові мають різну вагу залежно від їхньої лік- 
відності. Особливостями його запровадження в Україні є:

- нерозвиненість ринку ЦП та дефіцит високоякісних ліквідних активів (ВЛА), особливо у іноземній валюті (у зв'язку з чим при розробленні LCR ураховувалися: один рівень активів замість трьох $(1,2 \mathrm{~A}, 2 \mathrm{~B})$; вичерпний перелік ВЛА; ОВДП за вартістю, за якою приймаються як забезпечення за кредитами рефінансування);

- неможливість швидко i у значних обсягах конвертувати гривню у іноземну валюту для покриття відтоків у іноземній валюті (враховуються: валютні ОВДП зі строком до погашення >30 днів як гривневі активи; вимоги до LCR не тільки в єдиній валюті, але й в іноземній валюті);

- нерелевантність європейських критеріїв стабільності роздрібних депозитів (ураховуються депозити строкові і на вимогу замість стабільних i менш стабільних депозитів);

- найбільш стресовий сценарій 2014 р.; (БКБН розробив LCR на основі сценарію кризи 2007-2008 pp.) (здійснюється власне калібрування коефіцієнтів відтоків);

- законодавча заборона кредитів фізичним особам в іноземній валюті (коефіцієнт находжень $=100 \%$ замість 50\% (всі надходження залишаються в розпорядженні КБ і не йдуть на нове кредитування)) [1].

Це, звичайно, негативно позначається на борговій, інвестииійній, валютній безпеках, безпеці ліквідності $К Б$ зокрема і ФБКБ загалом.

Крім того, у вітчизняній практиці економічні нормативи $є$ по суті нормативами ліквідності балансу КБ, тоді БКБН розглядає їх як нормативи ліквідності бізнес-процесів банківських установ.
Водночас, позитивно на ліквідності КБ мають позначитися регуляторні новації НБУ, запроваджені регулятором останніми роками. Так, в 2016 р. НБУ було запроваджено новий інструмент екстреної підтримки ліквідності КБ - Emergency liquidity assistance - для покриття тимчасового дефіциту ліквідності КБ за вичерпання інших джерел i підтримки. КБ в 2017 р. було створено умови для більш ефективного управління своєю валютною ліквідністю завдяки збільшенню можливого обсягу купівлі валюти на міжбанківському ринку у власну позицію з 0,5\% до 1\% від розміру регулятивного капіталу, що позитивно позначилося на ресурсоутворювальній, кредитній, валютній безпеках, безпеиі ліквідності КБ і ФБКБ загалом.

Для більш точної оцінки ліквідності НБУ запровадив:

- у 2018 р. новий пруденційний норматив - коефіцієнт покриття ліквідністю (LCR) - мінімально необхідний рівень ліквідності для покриття чистого очікуваного відпливу коштів 3 КБ протягом 30 днів 3 урахуванням стрес-сценарію[2, с.22], що сприяло підвищенню рівня ресурсоутворювальної, депозитної безпек, безпеки ліквідності КБ і ФБКБ загалом;

- у лютому 2020 р. НБУ уточнив вимоги до виконання нормативу LCR в іноземній валюті для КБ, співвідношення зобов'язань яких в іноземній валюті до усіх зобов'язань становить менше 5\%. Такі КБ розраховуватимуть LCR в іноземній валюті для цілей нагляду, проте не матимуть зобов'язання забезпечувати дотримання його значення на рівні 100\%. Такий підхід зменшить регуляторне навантаження на КБ, які не працюють 3 іноземною 
валютою[3], сприятиме підвищенню рівня валютної безпеки, безпеки ліквідності КБ і ФБКБ загалом;

- у 2020-2021 pp. (з серпня і до кінця 2020 р. у тестовому режимі, 32021 - обов'язково для застосування) - коефіцієнт чистого стабільного фінансування або NSFR (англ. Net Stable Funding Ratio) (мінімальне значення не менше 100\%), який визначає мінімальний рівень ліквідності КБ на горизонті 1 рік та розраховується як співвідношення обсягу наявного стабільного фінансування (сума складових пасивів (регулятивний капітал та зобов'язання), зважених на установлені НБУ відповідні коефіцієнти, які відображають рівень їх стабільності) до обсягу необхідного стабільного фінансування (сума складових активів та позабалансових зобов'язань, зважених на установлені НБУ коефіцієнти, які характеризують їх ліквідність), що стало важливим кроком у гармонізації вимог до ліквідності українських КБ 3 нормами законодавства $\mathrm{CC}$ та рекомендаціями Базельського комітету після запровадження LCR та нових стандартів організації системи управління ризиками в КБ України[4]. Це має позитивно позначитися на ресурсоутворювальній безпеці, безпеизі ліквідності КБ і ФБКБ загалом. Водночас, слід зазначити, що застосування нормативу NSFR супроводжується кількома невирішеними питаннями, серед яких, зокрема, проблематичність залучення вітчизняними КБ стабільного довгострокового фінансування завдяки еміciï, а також необхідність при розрахунку цього нормативу аналізу власних історичних даних й певних припущень, що певною мірою знижує боргову, інвестииійну безпеки, безпеку ліквідності КБ і ФБКБ загалом;
- у серпні 2020 р. затвердив підхід до визначення справедливої вартості муніципальних облігацій, які можуть бути включені до пулу застав за кредитами рефінансування. Оцінка таких ЦП здійснюватиметься 3 урахуванням властивого їм кредитного ризику, який відповідає жорстким обмеженням, установленим Бюджетним кодексом України. Включення цих облігацій до пулу застав сприятиме розширенню інструментарію КБ 3 регулювання власної ліквідності, а також розвитку регіональних інфраструктурних проєктів та ринку ЦП загалом. Крім того, фінансова стійкість КБ також посилилася завдяки змінам законодавства у 2015 р. - відтоді вони отримали право не повертати вклади населення достроково на першу вимогу клієнтів. Це, безумовно, позитивно позначилося на ресурсоутворювальній, кредитній, депозитній, борговій складових зокрема і ФБКБ загалом;

- у 2020 р. КБ отримали можливість довгострокового рефінансування на строк до 5 років за відсотковою ставкою, що дорівнює ключовій ставці. Це дозволило зберігати ліквідність БС на високому рівні. 3 березня частоту планових тендерів 3 розміщення депозитних сертифікатів та надання короткострокових кредитів рефінансування було збільшено вдвічі. Також був подовжений строк надання кредитів рефінансування спочатку 314 до 30 днів, а пізніше й до 90 днів. Це дало можливість КБ за потреби, звертаючись до НБУ, оперативно покривати касові розриви ліквідності. Зменшення строковості депозитних сертифікатів 3 14 до 7 днів сприяло зростанню гнучкості в управлінні ліквідністю, зниженню невизначеності та поліпшенню очікувань учасників ринку[5, с.5,19], 
що, безумовно, позитивно впливатиме на підвищення безпеки ліквідності КБ і ФБКБ загалом.

Крім того, було розширено перелік прийнятної застави за кредитами для екстреної підтримки ліквідності КБ. Відтепер заставою за ELA можуть виступати майнові права за кредитними договорами $з$ юридичними особами не тільки в гривні, а й в іноземній валюті - доларах США та євро - 3 пониженими коригуючими коефіцієнтами; до переліку прийнятної застави також включені майнові права за кредитними договорами 3 юридичними особами п’ятого класу (раніше - не нижче четвертого), що має спричинити підвищення кредитної безпеки КБ.

Було внесено зміни і до порядку вирахування вартості непрофільних активів 3 капіталу КБ. 3 січня 2021 р. КБ мають зменшувати капітал на 25\% вартості непрофільних активів, що тривалий час зберігаються на їхніх балансах. Йдеться переважно про об'єкти житлової та комерційної нерухомості, які КБ стягнули як заставне майно за кредитами. 3 огляду на несприятливий вплив коронакризи на ринок нерухомості, НБУ продовжив 31 до 3 років період утримання майна на балансі без вирахування 3 капіталу. Адже КБ не мали змоги реалізувати отримані нещодавно активи до початку кризи. Після 2022 р. КБ повернуться до нормального графіка вирахування вартості непрофільних активів: для житлової нерухомості - через 2 роки, для інших активів - через 1 рік.

У другій половині 2021 р. відбулося підвищення ваг ризику для незабезпечених споживчих кредитів та розпочалася імплементація процесу оцінки КБ достатності внутрішнього капіталу i внутрішньої ліквідності (ICAAP/ILAAP).

З 1.04.2021 запроваджено NSFR як норматив на рівні 80\% 3 поетапним підвищенням до 100\% у квітні 2022 року. Впровадження цього нормативу спершу було заплановано на початок 2021 р., проте у зв’язку з підвищеним операційним навантаженням на КБ через пандемію відтерміноване на квартал. КБ вже проводять розрахунок NSFR у тестовому режимі із серпня 2020 року[6, с.41, 47].

Крім того, НБУ змінив графік проведення тендерів та строковість стандартних інструментів регулювання ліквідності. Розміщення депозитних сертифікатів та надання короткострокових кредитів рефінансування відтепер відбуватиметься вдвічі частіше. Двотижневі депозитні сертифікати стануть тижневими, а короткострокові кредити рефінансування, граничний строк яких раніше становив 14 днів, тепер видаються на строк до трьох місяців. Ставка за цими інструментами залишатиметься на рівні облікової ставки НБУ[2, с.43], що позитивно позначатиметься на ресурсоутворювальній, депозитній, кредитній безпеках $i$ безпеці ліквідності $K Б$ зокрема i ФБКБ загалом.

Водночас, як виявлено в ході дослідження, до вад регулятивноӥ й наглядової політики з дотримання вітчизняними КБ належного рівня ліквідноcmi можна віднести:

1) розвиток схемних способів залучення коштів 3 метою, яка принципово розбігається 3 нагромадженням заощаджень клієнтів[7, с.247]: залучення депозитів з метою: 1) фіктивного забезпечення наданих кредитів; 2) оптимізації податків на доходи громадян-власників підприємств; 3) виплати 
доходу акціонерами замість дивідендів; 4) підтримання ілюзорної ліквідності КБ, що підриває депозитну, кредитну безпеки, безпеки доходів $і$ витрат й ліквідності КБ зокрема i ФБКБ загалом;

2) поширення на МБР у 2008-2015 pp. схемних операцій з метою штучного підтримання ліквідності та «розбавлення» коштів фізичних осіб у пасивах для уникнення статусу спеціалізованого ощадного банку з необхідністю дотримання більш жорстких нормативів ліквідності, капіталу і кредитного ризику[7, с.255]: 1) два КБ укладали зустрічні угоди 3 розміщеннязалучення ресурсів в одній або різних валютах; 2) три і більше КБ укладали ланцюгові угоди для циркуляції ресурсів всередині «групи»; 3) один КБ виступав центральним контрагентом для кількох КБ, своєрідним вузлом. Це не може негативно не позначатися на ресурсоутворювальній, депозитній, кредитній безпеках, безпеиі ліквідності КБ зокрема і ФБКБ загалом.

Недоліки методичного забезпечення системи управління ліквідністю КБ зумовлюють зниження рівня ресурсоутворювальної, депозитної, кредитної безпек, безпеки ліквідності КБ зокрема і ФБКБ загалом.

Оскільки існуючі методики поодинці не можуть дати повною мірою обгрунтовану оцінку стану ліквідності КБ і ії впливу на ресурсоутворювальну, депозитну, кредитну, валютну, боргову, інвестииійну, податкову безпеки, безпеку доходів і витрат, безпеку у сфері міжнародних розрахунків $i$ платежів, безпеку ліквідності КБ зокрема і ФБКБ загалом, слід застосовувати комплексний підхід/синтез різних методичних підходів до такої оцінки.
Серед виявлених автором недоліків організації забезпечення ліквідності вітчизняних КБ доцільно виокремити:

1) відсутність ефективного механізму перерозподілу грошових коштів між КБ на МКР/забезпечення вільного перетоку грошових коштів між КБ;

2) вкрай незначний рівень іпотечного кредитування (за 2020 р. КБ надали іпотечних кредитів на 3,8 млрд грн, що на $36 \%$ більше порівняно з 2019 роком. Ринок житлової іпотеки залишається концентрованим: трохи менше 90\% нових кредитів видають 5 КБ. Майже всі нові видачі - це кредити на вторинне житло. Середня сума кредиту зростає, але умови кредитування залишаються консервативними. Якщо у 2019 р. середня сума кредиту становила близько 516 тис. грн, то у 2020 р. - 663 тис. грн. Середній розмір іпотечного кредиту на купівлю первинної нерухомості у 2020 р. становив 682 тис. грн, вторинної 660 тис грн) [8];

3) неврегульованість та непрозорість первинного ринку нерухомості, що створює ризики як для приватних інвесторів, так i для КБкредиторів (КБ віддають перевагу роботі із вторинним ринком: лише близько десятої частини нових кредитів надається на житло в новобудовах);

4) слабкі розвиток і ліквідність вітчизняного ринку ЦП.

Оцінка ліквідності вітчизняних КБ значною мірою подібна до зарубіжної практики, що дозволяе більшою мірою здійснювати компаративний аналіз й 3'ясовувати вплив ліквідних позицій КБ на окремі складові і ФБКБ загалом. Підтримка ліквідності КБ в Україні в 
основному подібна до світової практики.

Проведений дисертантом компаративний аналіз дозволив виявити, що спільними закономірностями в управлінні ліквідністю КБ країн світу, що вливають на забезпечення їх ФБ, є застосування таких адміністративних методів, як:

- заборона на здійснення КБ виробничої, підприємницької (що не відноситься до банківської), торговельної, інвестиційної і страхової діяльності (Казахстан, США, Україна та ін.);

- квотування окремих видів активних/пасивних операцій (наприклад, у США КБ заборонено безпосередньо володіти нерухомістю, придбавати звичайні акції корпорацій з огляду на високий ризик цих об'єктів вкладання коштів, що може в разі падіння цін на них спричинити зниження ліквідності КБ; у багатьох країнах директивно обмежено обсяг коштів населення, який окремий КБ може залучити для своєї діяльності; у Великій Британії встановлені обмеження на використання грошових коштів клієнтів у ризикованих цілях, а в Китаї КБ отримує чітке керівництво дій за спрямування коштів клієнтів на операції, пов’язані 3 ризиком[9]);

- унормування ліквідності балансу і достатності капіталу КБ; відрахування частини залучених КБ коштів у резервний фонд; валютного/відсоткового/ фінансового ризиків, що супроводжують функціонування КБ; встановлення лімітів на надання кредитів;

- розрахунок у багатьох країнах показників ліквідності КБ за співвідношенням активних і пасивних статей балансу, згрупованих за строками, які $\epsilon$ обов'язковими для виконання усіма
КБ (Японія, Франція, Велика Британія, Росія, Німеччина, Україна) [10, с.19];

- оцінка ліквідності КБ на основі грошового потоку;

- використання ЦБ зарубіжних країн подібних інструментів у забезпеченні ліквідності банківських секторів, як[11, с.88]: бюджетні вливання для підтримки внутрішнього попиту; зниження ставок рефінансування; надання гарантій за міжбанківськими кредитами та банківськими вкладами фізичних осіб; збільшення державної присутності в банківському секторі; рекапіталізація окремих КБ;

- зв’язування ЦБ надлишкової/нерівномірно розміщеної ліквідності КБ за допомогою управління ставкою грошового ринку, депозитних аукціонів за ставкою, близькою до операційного таргету $[12 ; 13 ; 14$, с.54];

- інформування

аудиторськими компаніями наглядових органів про неплатоспроможність КБ (у Великій Британії аудиторські компанії мають на це право, а Франції і Нідерландах зобов' язані це робити).

Як свідчить проведений дисертантом аналіз сьогоденної практики $y n$ равління вітчизняними КБ своєю ліквідністю, багато 3 них не мають обгрунтованої політики управління ризиком незбалансованої ліквідності, широкого арсеналу методів і сучасних інструментів управління ліквідністю, що, звичайно, знижує рівень їх $Ф Б$ загалом і їі окремих складових зокрема.

Проблемними аспектами управління ліквідністю вітчизняних КБ, що негативно позначаються на підвищенні їх ФБ, на наше переконання, є:

- управління КБ своєю ліквідністю на основі концепцій, методів й інструментів, прийнятних переважно для стану відносної економічної стабільності; 
- складність достовірної оцінки ліквідності, зумовлена часто умовним характером розподілу коштів КБ на активи і пасиви (скажімо, до пасивів до запитання входять залишки на рахунках юридичних осіб, карткових зарплатних рахунках, коррахунки інших КБ, депозити до запитання юридичних і фізичних осіб);

- несвоєчасна й неадекватна оцінка мінливості рівня ліквідності фінансового ринку і неспроможність КБ в окремих випадках взагалі залучати кошти на ньому;

- значна частка у грошовій масі в обігу готівки поза банками; обмеженість державної підтримки КБ (короткостроковість кредитів НБУ КБ, їх використання, в основному для регулювання миттєвої ліквідності останніх, вузький перелік інструментів рефінансування, їх доступу на міжнародні ринки капіталу й надмірна залежність від міжбанківського кредитного ринку; відплив вкладів і скорочення ресурсної бази кредитування; висока частка прострочених кредитів;

- незбалансованість

активнопасивних операцій за строками;

- мінливість накопиченої і покупної ліквідності, що спричиняє іiі дефіцит унаслідок дисбалансу операцій;

- вкрай низька частка у КБ ліквідних (за Базелем III) ЦП з високими рейтингами;

- використання тривалий час як керівництва до дії лише нормативів НБУ, що змушували КБ оцінювати ризики ліквідності, позаяк була відсутня потреба у механізмах управління ліквідністю, зумовлена надлишковою ліквідністю, значною часткою ОВДП у портфелях КБ;

- не відображення розрахунками дотримання нормативів ліквідності реа- льної ситуації, недосконалість формул їх визначення внаслідок використання випадкових високо варіабельних величин, методи оцінки яких не регламентовані;

- неврахування нормативами ліквідності значущості ризику втрати динамічної ліквідності, позаяк ліквідність розраховується на 1 день/місяць/рік, залишаючи невідомими проміжкові стани ліквідності КБ;

- нехтування нормативами концентрації зобов'язань/крупних вкладів, що також, як і у випадку концентрації активів, небезпечно для КБ;

- не гарантування КБ відсутності проблем 3 ліквідністю в майбутньому за дотримання нормативів ліквідності, оскільки останнє хоча й є необхідною, проте недостатньою умовою фінансових стійкості/стабільності функціонування КБ;

- падіння корисності нормативів ліквідності мірою зростання їх абсолютних значень (особливо на позначці $100 \%)$;

- поступове зниження значущості нормативів обов'язкових резервів як регуляторів ліквідності, позаяк спостерігається достатньо незначний внесок обов'язкового резервування у формування ліквідності грошового ринку, що свідчить що в сьогоденних умовах воно не $є$ ключовим каналом абсорбування надлишкової ліквідності, будучи допоміжним регулятивним інструментом;

- створення нерівних конкурентних умов, що погіршують фінансові показники внаслідок різного характеру впливу резервних вимог на стан ліквідності КБ; обмеження можливостей КБ виконувати функцію каталізатора економічного зростання внаслідок 
підвищення регуляторного навантаження;

- не виключення маніпулювання інформацією та штучного збільшення ліквідних активів (операції з залучення міжбанківських кредитів на ностро рахунки КБ-кредитора, що збільшує активну базу, та тим самим збільшує значення нормативу миттєвої ліквідності, перерахування коштів афілійованих юридичних осіб на депозитні рахунки, 3 достроковим розірванням (як правило, на наступний робочий день) депозитної угоди та поверненням коштів на поточні рахунки) унаслідок уніфікованого підходу до розрахунку нормативів ліквідності. Про поширення операцій 3 маніпулювання показниками ліквідності свідчить динаміка виконання нормативів ліквідності «проблемних» КБ, в яких криза ліквідності спричинила затримку виконання зобов'язань перед кліснтами та здійснення заходів щодо введення тимчасової адміністрації[15, с.78];

- відмінність оцінки розрахункових коефіцієнтів ліквідності за централізованого контролю і децентралізованого аналізу (з огляду на можливість оскарження підрозділом фінмоніторингу НБУ здійснюваних КБ непрямої підтримки тіньових операцій);

- достроковий продаж частини менш ліквідних активів за високої ймовірності продажу за ціною нижче балансової/втрати їх частини (різниця між балансовою й ринковою ціною), що зумовлено відсутністю стійкого попиту, а відтак, стійких котирувань на ці активи;

- збільшення витрат 3 підтримки ліквідності внаслідок упровадження жорстких вимог зі створення резервів ліквідності;
- складність оптимізувати депозитні, кредитні, інвестиційні портфелі КБ унаслідок специфічних завдань останніх, залежності їх стратегічних рішень від чинників, прогнози яких недоступні для окремих банківських установ, відсутності обгрунтованих моделей управління активами і пасивами;

- відсутність у окремих КБ політики 3 управління ліквідністю і відповідних підрозділів 3 покладанням обов'язків 3 управління ліквідністю на відповідальних виконавців різних підрозділів КБ; формальний підхід до затвердження внутрішньобанківських документів 3 цієї проблематики, що супроводжується необгрунтованою політикою фондування; низька якість управління ліквідністю;

- покладання відповідальності за прийняття рішень $з$ управління ліквідності лише на відповідний структурний підрозділ КБ 3 функціональною підпорядкованістю відділів, діяльність яких пов'язана 3 управлінням ліквідністю, що йде в розріз рекомендаціям БКБН, який зазначає, що ключова роль в такому управлінні має належати правлінню і менеджменту КБ;

- дублювання функцій 3 управління ліквідністю у великих КБ;

- відсутність/недостатній рівень координації управління ліквідністю в КБ чи виконання таких функцій управління нею, як: стратегічне й антикризове планування; необхідної оперативності зі зміни інформаційних потоків, функцій і зв'язків спеціалістів 3 управлінню ліквідністю за зміни умов діяльності КБ;

- відсутність належної внутрішньої звітності для вирішення завдань з управління ліквідністю і належного контролінгу ризиків утрати/зниження/ недостатньої (від'ємної, дефіцит- 
ної)/надлишкової/

незбалансова-

ної/неможливості отримання грошових коштів/збитків через необхідність здійснення швидкої конверсії фінансових актвів/нерівномірного розподілу ліквідності КБ;

- недостатній контроль за якістю управління i виконання управлінських рішень; низька якість застосування контролінгу ризиків втрати/недостатності/ надлишковості/незбалансованості ліквідності;

- недосконалість стрес-тестування ризиків у утрти/недостатньої/надлишкової/ незбалансованої ліквідності в частині припущень та використання результатів тестів для прийняття рішень у КБ з управління активами і пасивами; створення запасу ліквідності (по-перше, запас ліквідності може бути використаний дуже швидко під час масового вилучення вкладів; по-друге, у разі залучення вкладів в іноземній валюті та розміщення в дохідні активи у гривні КБ буде нездатний повернути депозити навіть частині занепокоєних вкладників; по-третє, надмірний запас ліквідності обтяжує баланс КБ, обмежує його здатність генерувати прибуток на дохідні активи. Відтак, запас ліквідності не знімає з керівництва КБ відповідальності за зміцнення довіри клієнтів до нього), оцінки тривалості стресу ліквідності (яка може значно перевищувати термін у 30 днів); оцінки потенціалу підтримки КБ власниками у період кризи ліквідності (оскільки акціонери часто відмовляються допомагати КБ, якщо вбачають в цьому вигоду для збереження активів своїх ФПГ) та можливості вилучення депозитів акціонерами й відомими політиками, чиновниками[16, с.109]; істотна відмінність результативності стрес-тестування ліквідності (вияв- лення розміру дефіциту і кількості КБ, в яких він спостерігається), проведеного за різними методиками (з урахуванням різних ситуацій);

- зниження дохідності КБ за формування надмірних резервів ліквідності, високі відсотковий ризик і ризик неплатоспроможності за підтримки ліквідності шляхом купівлі активів на грошовому ринку в разі утворення іii розривів;

- існуючі в ряді випадків нераціональні параметри співвідношення накопиченої ліквідності (грошові резерви/резерви другої черги покупної ліквідності/сукупні кредитні ліміти КБ);

- проблемне визначення сукупної потреби КБ у ліквідності;

- відсутність достовірної оцінки впливу на фінансовий стан КБ будьякого погіршення ліквідності на фінансових ринках та підвищення нестабільності на валютних ринках та ринках капіталу;

- несвоєчасне виконання платежів/умисне відтермінування КБ платежів для економії власної ліквідності; неможливість визначення величини незапланованих операцій;

- наявність за кризових ситуацій нестачі як покупної (унаслідок скорочення грошової пропозиції), так і накопиченої (за порушення графіків обслуговування кредитів, їх пролонгації) ліквідності; обмеженість джерел іi підтримки в таких ситуаціях;

- обмежений перелік якісних i, водночас, високодохідних інструментів, що обертаються на біржових ринках, що дозволяють КБ збільшувати маржеві доходи без значної шкоди для їх ліквідності;

- втрати від операцій 3 управління ліквідністю/додаткові витрати, зумовлені розмішенням коштів у високолік- 
відні активи, залучення коштів 3 фінансового ринку 3 метою покриття дефіциту ліквідності/розміщення надлишків ліквідності на цьому ринку, продаж активів за вартістю нижче балансової.

До недоліків бухгалтерського обліку ліквідності КБ та відповідної звітності, на наш погляд, можна віднести: - визначення іiі стану за даними про активи і зобов'язання балансу КБ на певну дату без обліку змін їх величини і структури на минулу дату;

- неможливість аналізу за даними офіційної фінансової звітності КБ ліквідності активів за клієнтськими сегментами в розрізі фізичних та юридичних осіб;

- відсутність розрахунків ліквідності для обслуговування сукупних зовнішніх зобов'язань КБ;

- недостатнє впорядкування віднесення до витрат страхових резервів під нестандартну заборгованість за кредитними операціями у податковому обліку прибутку КБ;

- відсутність обліку ліквідних грошових коштів, отриманих на фінансовому ринку як прибуток;

- недосконалість стандартів бухгалтерського обліку при аналізі ліквідності КБ;

- неточність даних за обліку фінансових активів/зобов' язань КБ, що сприяють підвищенню складності і ризику недотримання обгрунтування бізнесмоделі;

- складність оцінки ліквідності і ризику невиконання зобов'язання контрагентом у разі використання позабіржових інструментів;

- виведення вартості ризиків, закладених у складні структуровані продукти, на основі неналежних статистичних моделей;
- не віднесення електронних грошей, емітованих іншими КБ, до складу високоліквідних активів;

- відсутність у МСФЗ явного посилання на ліквідність.

Серед прогалин сучасного інформаизйно-аналітичного середовища підтримання ліквідності для забезпечення ФБКБ, на наш погляд, слід виокремити такі:

- відсутність до березня 2018 р. оприлюдненої всіма без виключення КБ інформації про дотримання нормативів ліквідності, що компенсувалось переважно інформацією щодо іiі розривів;

- невизначеність позиції КБ зі здійснюваних платежів на певний момент часу в управлінні їх ліквідністю зумовлена платежами за незапланованими операціями і погрішністю за прогнозованими платежами, що спричинено побоюваннями кліснтів 3 приводу стійкості КБ; погіршенням економічної кон'юнктури, що позначається на фінансовому стані учасників ринку банківських послуг; вилученням з КБ найбільш крупних депозитів, яке може бути додатковим імпульсом зниження його ліквідності;

- існування великої невизначеності стосовно майбутньої ситуації з ліквідністю в БС унаслідок нестачі інформації на рівні окремих КБ, а також раптових різких коливань;

- нестачу у багатьох КБ сучасних інформаційно-комунікаційних технологій, що повинні включати сховища даних, методи їх обробки й аналізу;

- часовий розрив між моментом доступу до інформації про платіж між банком-одержувачем i часом переказу коштів, що спричиняє ризик, пов’язаний $з$ передачею платіжних повідомлень; 
- відсутність достатнього статистичного масиву зі структури платежів КБ у розрізі строків, валют, інструментів, структурних підрозділів для застосування статичних методів аналізу і моделювання ліквідності.

До недоліків кадрового забезпечення підтримання ліквідності для забезпечення ФБКБ, на наш погляд, слід віднести:

- значний розрив у рівні професійної підготовки фахівців, що займаються у КБ ризик-менеджментом;

- розбіжності інтересів експертів, аналітиків й осіб, що приймають кінцеві рішення в управлінні ліквідністю КБ;

- відсутність необхідних навичок і технологій колективного прийняття рішень з управління ліквідністю;

- часту розрізнену діяльність фахівців 3 дотримання ліквідності і забезпечення ФБКБ.
До нерозв'язаних й досі питань технологічного забезпечення підтримання ліквідності для забезпечення ФБКБ, на наш погляд, належать:

- відсутність в КБ ситуаційних центрів для сценарного моделювання ліквідності зокрема і ФБКБ загалом;

- перебої у дистанційному банківському обслуговуванні.

Висновки. Отже, як виявило вперше проведене автором всебічне дослідження, підсистемам управління ліквідністю у забезпеченні ФБКБ, попри наявні позитивні риси, притаманні й численні недоліки. Відтак, вони потребують подальшого вдосконалення. Останнє має здійснюватись комплексно, за участю і координацією зусиль усіх суб'єктів управління ліквідністю для підвищення рівня ФБКБ.

\section{Список використаної літератури}
1. Стандарти
управління
ліквідністю
банків.
URL:

https://old.bank.gov.ua/doccatalog/ document?id=69900831 (дата звернення: 10.09.2021)

2. Звіт про фінансову стабільність. Червень 2020 року. К, 2020. 51 с.

3. Національний банк уточнює вимоги до виконання банками LCR в іноземній валюті. URL: https://bank.gov.ua/ua/news/all/natsionalniy-bank-utochnyuye-vimogido-vikonannya-bankami-lcrv-inozemniy-valyut (дата звернення: 10.09.2021)

4. Національний банк запроваджує новий норматив довгострокової ліквідності для банків - NSFR. URL: https://bank.gov.ua/ua/news/all/natsionalniy-bankzaprovadjuye-noviy-normativ-dovgostrokovoyi-likvidnosti-dlya-bankiv--nsfr (дата звернення: 10.09.2021)

5. Звіт Національного банку України за 2020 рік. К.: НБУ. 2021. 40 с.

6. Звіт про фінансову стабільність. Грудень 2020 року. К.: НБУ. 2021. 49 с.

7. Панасенко Г. О. Механізми залучення фінансових ресурсів комерційними банками в Україні: дис... д-ра екон. наук: 08.00.08. К., 2017. 523 с. 
8. Річний звіт Державної іпотечної установи за 2020 рік. URL: http://ipoteka.gov.ua/sites/default/files/FIN_ZVIT2020.pdf (дата звернення: 10.09.2021)

9. Общество и государство в Китае: T. XLIII, ч. 2 / Редколл.: А.И. Кобзев и др. Иностранные инвестиции в китайский банковский сектор: проблемы эффективности. URL: http://www.synologia.ru/a/Иностранные_инвестиции_в_ китайский_банковский_сектор:_проблемы_эффективности.

10. Міщенко В. І., Сомик А. В. Ліквідність банківської системи України: Науково-аналітичні матеріали. Вип. 12. К.: Центр наукових досліджень Національного банку України, 2008. 180 с.

11. Максимова Ю. А. Инструменты государственного управления ликвидностью банковских систем ведущих стран мира в условиях мирового финансового кризисна. Современные тенденциии развития науки и технологий, 2016. № 10-9. C.80-89.

12. Mrlikova M. Managing Surplus Liquidity (Czech National Bank). Bundesbank Expert panel on «Managing Surplus Liquidity». Frankfurt am Main, August 2012.

13. Заторски П. М. Управление ликвидностью в условиях ее избытка в Польше. Управление ликвидностью банковского сектора в центральных банках: материалы круглого стола, г. Тула, 4-7 сентября 2012 г.

14. Юркова Г. В. К вопросу об избыточной банковской ликвидности. Деньги $u$ кредит, 2013. № 4. С.47-59.

15. Гурський Д. Ю. Перспективи коефіцієнтного аналізу як засобу оцінки ліквідності банківської системи. Вісник КНУТД. Серія «Економічні науки», 2015. №2. C.74-83.

16. Ткачук В. О. Моделювання ліквідності банку з урахуванням стандартів Базеля III. Наукові праці НДФІ, 2014. № 2. С.105-116. 